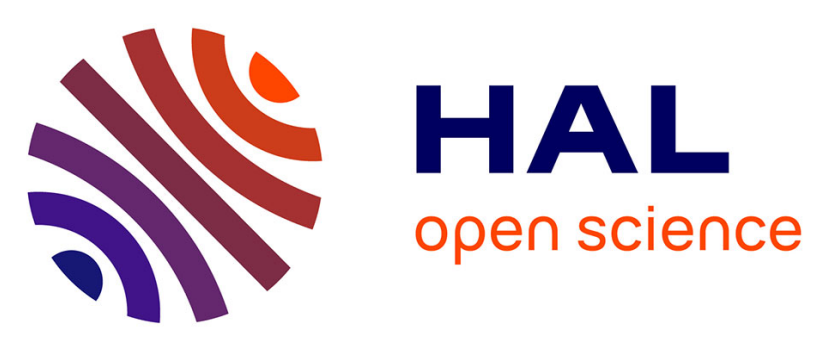

\title{
Halogen and chalcogen-bonding interactions in sulphur-rich $\pi$-electron acceptors
}

\author{
Y. Le Gal, A. Colas, F. Barrière, V. Dorcet, T. Roisnel, D. Lorcy
}

\section{To cite this version:}

Y. Le Gal, A. Colas, F. Barrière, V. Dorcet, T. Roisnel, et al.. Halogen and chalcogen-bonding interactions in sulphur-rich $\pi$-electron acceptors. CrystEngComm, 2019, 21 (12), pp.1934-1939. 10.1039/c8ce02046a . hal-02090018

\section{HAL Id: hal-02090018}

\section{https://hal-univ-rennes1.archives-ouvertes.fr/hal-02090018}

Submitted on 17 Apr 2019

HAL is a multi-disciplinary open access archive for the deposit and dissemination of scientific research documents, whether they are published or not. The documents may come from teaching and research institutions in France or abroad, or from public or private research centers.
L'archive ouverte pluridisciplinaire HAL, est destinée au dépôt et à la diffusion de documents scientifiques de niveau recherche, publiés ou non, émanant des établissements d'enseignement et de recherche français ou étrangers, des laboratoires publics ou privés. 


\title{
Halogen and chalcogen-bonding interactions in sulphur-rich $\pi$ - electron acceptor
}

\author{
Yann Le Gal, Adrien Colas, Frédéric Barrière, Vincent Dorcet, Thierry Roisnel and Dominique \\ Lorcy*
}

In order to explore the feasibility of generating halogen bonding interactions between sulphur-rich $\pi$-electron acceptors, we prepared three bithiazolidinylidene derivatives substituted by iodine atoms, namely the $3,3^{\prime}$-bis(iodophenyl) bithiazolidinylidene-2,4,2',4'-tetrathione (BIP-BTTT). Sulphur and iodine heteroatoms were introduced on the skeleton of the acceptor molecule to induce chalcogen $\cdots$ chalcogen and halogen bonding interactions. Both interactions can be evidenced by X-ray diffraction studies in the synthetic precursors as well as in the acceptors themselves.

\section{Introduction}

The design of molecules for the elaboration of semi-conducting molecular materials relies essentially on the intrinsic properties of the molecular precursors. However, the properties of the materials are also based on the solid state organization and on the intermolecular interactions between molecules within the material. ${ }^{1-2}$ Indeed, weak interactions between molecules will result into an insulating material with no charge carrier delocalization. Various types of intermolecular interactions have been explored such as chalcogen $\cdots$ chalcogen contacts, ${ }^{3}$ hydrogen bonding, ${ }^{4-5} \pi-\pi$ stacking, ${ }^{6}$ halogen bonding, ${ }^{7}$ either separately or cooperatively. ${ }^{8}$ In this context, we recently developed the synthesis of sulphur-rich electron acceptors with a bithiazolidinylidene-2,4,2',4'-tetrathione (BTTT) backbone (Chart 1). ${ }^{9}$

\section{Chart 1}

BTTT<smiles>[R]N1S/C(=C2/SC(=S)N([R])C2=S)SC1=S</smiles>

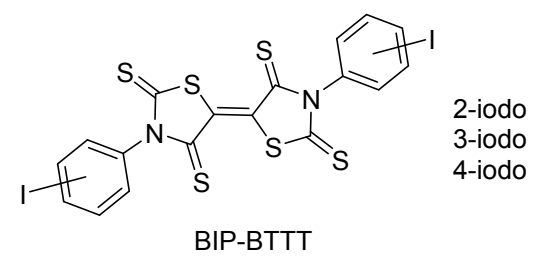

BIP-BTTT
Several members of this family led to air-stable n-channel organic field effect transistors (OFET) exhibiting good performances. ${ }^{10,11}$ The air stability and the enhanced charge mobility were ascribed to the presence of S...S intermolecular interactions. ${ }^{10}$ As the intermolecular interactions are of high importance for the charge mobility as well as for the stability of

Univ Rennes, CNRS, ISCR (Institut des Sciences Chimiques de Rennes) - UMR 6226, F-35000 Rennes, France.Email : Dominique.lorcy@univ-rennes1.fr

† Electronic Supplementary Information (ESI) available: crystallographic data in CIF format. CCDC 1872721-1872724. See DOI: 10.1039/x0xx00000x n-channel OFET, ${ }^{12}$ we focused our interest on other interactions than the chalcogen $\cdots$ chalcogen contacts. For that purpose, we investigated the synthesis of similar acceptors substituted with halogen atoms such as iodine, potentially able to form halogen bonds $(\mathrm{XB})$ with the chalcogen atoms of the neighbouring molecules, acting as XB acceptors. Indeed, we recently reported for example that the exocyclic sulphur atom in thiazoline-2thiones can act as an efficient $X \mathrm{~B}$ acceptor toward organic iodinated molecules. ${ }^{13}$ Therefore we investigated the synthesis of 3,3'-bis(iodophenyl)-BTTT, BIP-BTTT (Chart 1) where the nitrogen atom of the heterocyles, the thiazoline-2-thione moieties, are substituted by an ortho, meta or para iodophenyl moiety. These different substitution patterns led to the analysis of the influence of the localization of the halogen atom on the intermolecular interactions. In this study, we report the syntheses and X-ray structure investigations of the precursors and the novel electron acceptors BIP-BTTT. Electrostatic surface potential (ESP) calculations carried out on four of the crystallographically characterized compounds provide a complementary understanding of the organization of the molecules in the solid state.

\section{Results and Discussion}

The strategy we used to synthetize the acceptors BIP-BTTT 4a-c starting from the 2-, 3- and 4-iodoaniline is outlined in Scheme 1. Addition of triethylamine to a solution of the iodoaniline in carbon disulphide led to the dithiocarbamate salts $1 \mathbf{1 a - c}$ in good yields. Alkylation of 1a-c with chloroethanal followed by cyclization and dehydration in the presence of sulphuric acid allowed us to isolate the thiazoline-2-thione $\mathbf{2 a - c}$. The next step consists in the construction of the fused dithiole-2-one rings on the thiazoline-2-thione 2a-c. Successive addition of LDA and sulphur to thiazoline-2-thione $\mathbf{2 a - c}$ followed by the addition of triphosgene afforded the dithiol-2-one 3a-c. We previously demonstrated that a thermal treatment of such protected dithiolene ligands within a dithiol-2-one cycle is an efficient 
strategy for the synthesis of the acceptor skeleton. ${ }^{9}$ The acceptors BIP-BTTT 4a-c were therefore synthetized by simply heating the bicyclic structures 3a-c into refluxing toluene. These acceptors 4a-c were obtained as deep purple compounds poorly soluble in common organic solvents, the less soluble one being para-substituted $\mathbf{4 a}$.

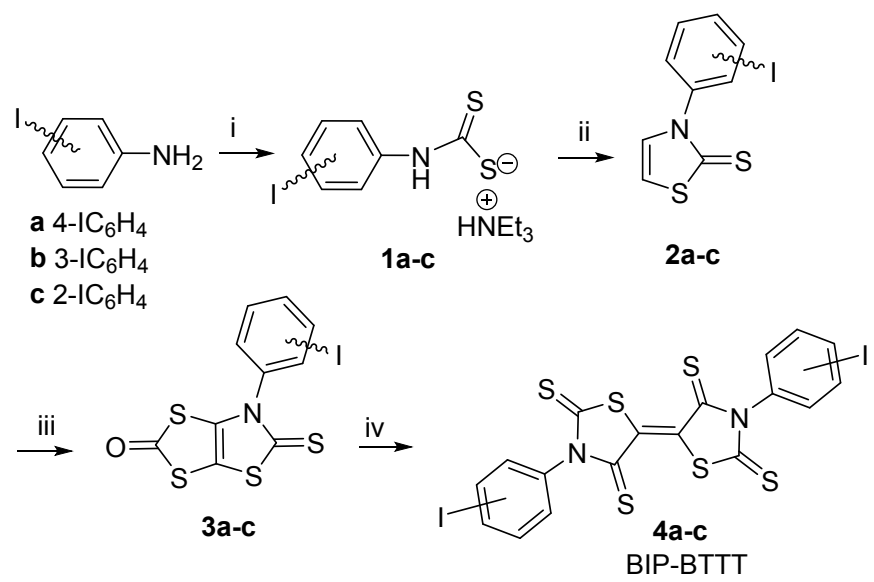

Scheme 1. Synthetic path to BIP-BTTT derivatives 4a-c, 26-36\% yield from 2a-c. Reactants and conditions: i) $\mathrm{CS}_{2}, \mathrm{NEt}_{3}$; ii) $\mathrm{ClCH}_{2} \mathrm{CHO}, \mathrm{H}_{2} \mathrm{SO}_{4}$; iii) LDA, $\mathrm{S}_{8},\left(\mathrm{Cl}_{3} \mathrm{CO}\right)_{2} \mathrm{CO}$; iv) toluene, $\Delta$.

Electrochemical investigations carried out by cyclic voltammetry allowed us to determine the redox potentials of these derivatives. They were performed in DMSO for the three acceptors $\mathbf{4 a - c}$ and in $\mathrm{CH}_{2} \mathrm{Cl}_{2}$ for $\mathbf{4 b - c}$; $\mathbf{4 a}$ being not soluble enough in dichloromethane. The redox potentials are collected in Table 1 together with those of DEBTTT ( $R=E t$, Chart 1$)$ for comparison. Two reversible monoelectronic reduction waves are observed for these three acceptors, either in DMSO or in $\mathrm{CH}_{2} \mathrm{Cl}_{2}$, attributed to the successive reduction of the acceptor into the radical anion and the dianion. Compared to DEBTTT, in both solvents the redox potentials of the acceptors $4 a-c$ are slightly shifted towards more anodic potentials indicating a weak effect of the iodophenyl substituent on the overall accepting ability of these molecules. 4a-c and DEBTTT exhibit slightly lower electron accepting ability than TCNQ $\left(E_{1}=0.18 \mathrm{~V}\right.$ and $E_{2}=-0.37 \mathrm{~V}$ vs SCE). ${ }^{14}$

Table 1 Redox potentials $\mathrm{E}_{1 / 2} \mathrm{~V}$ vs SCE, in $\mathrm{CH}_{2} \mathrm{Cl}_{2}$ and DMSO for DEBTTT and 4a-c

\begin{tabular}{ccccc}
\hline & \multicolumn{2}{c}{$\mathrm{CH}_{2} \mathrm{Cl}_{2}$} & \multicolumn{2}{c}{ DMSO } \\
\hline Acceptors & $\mathrm{E}_{1 / 2}{ }^{1}$ & $\mathrm{E}_{1 / 2}{ }^{2}$ & $\mathrm{E}_{1 / 2}{ }^{1}$ & $\mathrm{E}_{1 / 2}{ }^{2}$ \\
DEBTTT & -0.05 & -0.44 & 0.06 & -0.41 \\
4a & & & 0.09 & -0.33 \\
4b & -0.01 & -0.43 & 0.1 & -0.34 \\
4c & -0.04 & -0.48 & 0.05 & -0.37 \\
\hline
\end{tabular}

Crystals of sufficient quality for an X-ray diffraction study were obtained by slow concentration of a $\mathrm{CH}_{2} \mathrm{Cl}_{2}$ solution of $\mathbf{2} \mathbf{b}, \mathbf{3 a}$ and $\mathbf{3 c}$ as well as from a $\mathrm{CHCl}_{3}$ solution of the acceptor $\mathbf{4 c}$. The molecular structure of $\mathbf{2 b}$ is reported in Figure 1 . The thiazole core is planar, while the phenyl ring is located in a plane forming a dihedral angle of $63.4(5)^{\circ}$ with the thiazoline-2-thione core. The sulphur atoms can behave as a Lewis base and form intermolecular halogen bonding with the iodine atom of a neighbouring molecule. ${ }^{13,15}$ However in $\mathbf{2 b}$, only a short distance between the hydrogen atom of the thiazoline ring and the sulphur atom of the thione $(2.788$ (4) $\AA$ ), assigned to an hydrogen bond $(\mathrm{HB})$, was observed.

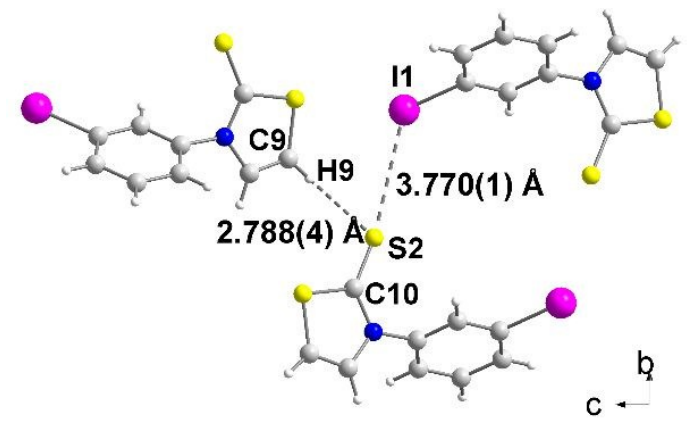

Fig. 1 View of the $\mathrm{C}-\mathrm{H} \cdots \mathrm{S}=$ and $\mathrm{C}-\mathrm{I} \cdots \mathrm{S}=$ interactions on the $b c$ plane for $\mathbf{2 b}$.

Table 2 Revelant interatomic distances $(\AA)$ and angles $\left({ }^{\circ}\right)$ for the halogen bonding, hydrogen bonding and chalcogen interactions. The van der Waals contact distances amount to

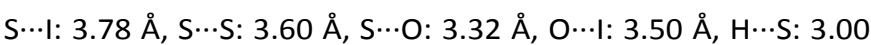
Å.

\begin{tabular}{|c|c|c|c|}
\hline & Distances $(\AA ̊)$ & $\overline{\text { Ang }}$ & $\operatorname{les}\left({ }^{\circ}\right)$ \\
\hline$\overline{2 b}$ & $\mathrm{~S}_{2} \cdots \mathrm{H} 2.788(4)$ & $\mathrm{C}_{9}-\mathrm{H}_{9} \cdots \mathrm{S}_{2} 175.9(3)$ & $\mathrm{H}_{9} \cdots \mathrm{S}_{2}=\mathrm{C}_{10} 98.4(2)$ \\
\hline $3 a$ & $\mathrm{O}_{1} \cdots \mathrm{I}_{1} 3.271(12)$ & $\mathrm{C}_{8}-\mathrm{I}_{1} \cdots \mathrm{O}_{1} 161.4(4)$ & $\mathrm{I}_{1} \cdots \mathrm{O}_{1}=\mathrm{C}_{4} 109.2(8)$ \\
\hline & $\mathrm{S}_{1} \cdots \mathrm{S}_{3} 3.329(4)$ & & \\
\hline $3 c$ & $\mathrm{O}_{12} \cdots \mathrm{I}_{1} 3.252(5)$ & $\mathrm{C}_{1}-\mathrm{I}_{1} \cdots \mathrm{O}_{12} 154.6(9)$ & $\mathrm{I}_{1} \cdots \mathrm{O}_{12}=\mathrm{C}_{11} 111.1(2)$ \\
\hline & $\mathrm{S}_{2} \cdots \mathrm{S}_{4} 3.416(1)$ & & \\
\hline $4 c$ & $S_{15} \cdots I_{2} 3.763(7)$ & $C_{21}-I_{2} \cdots S_{15} 155.5(5)$ & $\mathrm{I}_{2} \cdot \mathrm{S}_{15}=\mathrm{C}_{64} 118.7(6)$ \\
\hline & $\mathrm{S}_{16} \cdots \mathrm{I}_{1} 3.390(11)$ & $\mathrm{C}_{1}-\mathrm{I}_{1} \cdots \mathrm{S}_{16} 158.2(3)$ & $\mathrm{I}_{1} \cdots \mathrm{S}_{16}=\mathrm{C}_{62} 119.4(6)$ \\
\hline & $S_{5} \cdots I_{11} 3.533(4)$ & $\mathrm{C}_{51}-\mathrm{I}_{11} \cdots \mathrm{S}_{5} 156.3(3)$ & $C_{12}=S_{5} \cdots I_{11} 124.9(5)$ \\
\hline & $S_{3} \cdots S_{6} 3.177(7)$ & & \\
\hline
\end{tabular}

The molecular structures of dithiol-2-ones $\mathbf{3 a}$ and $\mathbf{3 c}$ are reported in Figure 2. For both derivatives the dithiol-2-one and the fused thiazoline core are coplanar and form with the plane of the aromatic substituent a dihedral angle of $50.5(2)^{\circ}$ for $3 a$ and $100.2(3)^{\circ}$ for 3 c. Short $1 \cdots 0$ contacts are observed between two neighbouring molecules of $3.271 \AA$ for $3 a$ and $3.252 \AA$ for 
3c, corresponding to a reduction ratio of $93.4 \%$ and $92.9 \%$ respectively, relative to the van der Waals contact distance (3.50 Å), indicating a sizeable XB interaction between neighbouring molecules (Figure $2 \mathrm{a}$ and $2 \mathrm{~b}$ ). ${ }^{16}$ The $\mathrm{C}-\mathrm{I} \cdots \mathrm{O}$ angles, at $161.4^{\circ}$ and $154.6^{\circ}$, are here closer to linearity and consistent with an $\mathrm{XB}$ interaction. In addition, for both structures, chalcogen $\cdots$ chalcogen contacts are also observed between neigboring molecules, at a distance shorter than the sum of the van der Waals radii, either of the two sulphur centers (3.60 A) or the sulphur and the oxygen atoms (3.32 $\AA$ ). The shortest sulphur...sulphur contacts measured for $\mathbf{3 a}$ and $\mathbf{3 c}$ are reported in Figures $2 \mathrm{c}$ and $2 \mathrm{~d}$. The crystal structure of 3 a reveals $\mathrm{S} \cdots \mathrm{O}$ and S...S distances of 3.274(12) $\AA$ and 3.329(5) A respectively, the latter corresponds to $93 \%$ of the van der Waals distance and is due to strong non covalent bonding between two molecules. Comparatively the $\mathrm{S} \cdots \mathrm{S}$ distances within $\mathbf{3 c}$ (the shortest being 3.416(1) A) are longer than in 3a. This is ascribed to a steric effect in the solid state of the ortho position of the iodine atom on the phenyl ring.

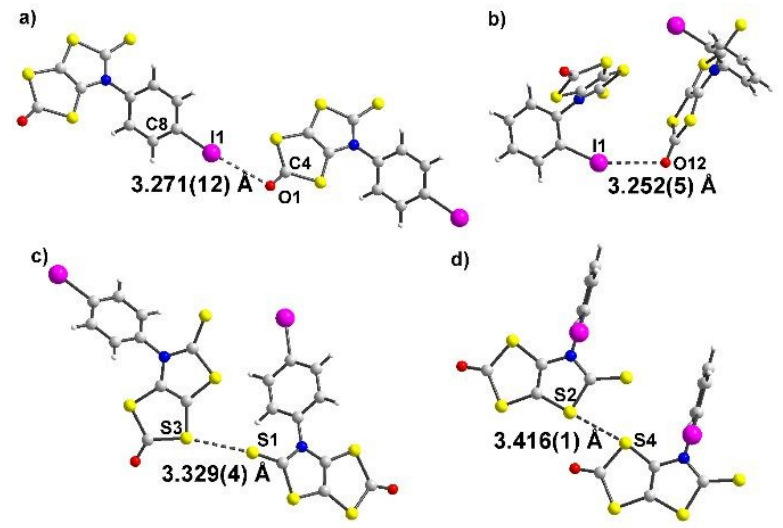

Fig. 2 View of the XB interactions, $O \cdots \mid$ contacts shorter than the sum of the van der Waals radii in dark grey dotted lines in 3a (a) and $3 \mathrm{c}(\mathrm{b})$. View of the chalcogen interactions, S...S contacts shorter than the sum of the van der Waals radii in dark grey dotted lines in $\mathbf{3 a}(\mathrm{c})$ and $\mathbf{3 c}(\mathrm{d})$.

Among the three electron acceptors, only the ortho substituted derivative $\mathbf{4 c}$ could be analysed by $\mathrm{X}$-ray diffraction study. The molecular structure of this derivative is presented in Figure 3 . It crystallizes in the triclinic system, space group $\mathrm{P}-1$, with two crystallographically independent molecules in the unit cell in general position. This acceptor exhibits a planar skeleton and a trans configuration of the two thiazoline-2-thione rings with short intramolecular S...S contacts between the $S$ atom of a thiocarbonyl group and the $S$ atom of the thiazole ring $(2.94$ $\AA / 2.91 \AA)$. These short $\mathrm{S}$...S contacts are in the same range as those observed for different acceptors belonging to the same family. ${ }^{9}$

Interestingly, the ortho-iodophenyl substituents on the nitrogen atoms have a similar orientation with the iodine pointing in the same direction above the plane of the acceptor. The plane of the phenyl rings is almost perpendicular to the plane of the acceptor. The molecules are associated through $\mathrm{I} \cdots \mathrm{S}=\mathrm{C}$ XB interaction networks between $\mathrm{I}_{1} \cdots \mathrm{S}_{16} 3.390(11) \AA$ and $\mathrm{I}_{11} \cdots \mathrm{S}_{5}$ 3.533(11) $\AA$ for the most significant short distances corresponding respectively to $89.7 \%$ and $93.4 \%$ of the van der Waals distances. Besides these intramolecular contacts, short S...S intermolecular contacts are also observed between neighbouring molecules, $\mathrm{S}_{3} \cdots \mathrm{S}_{6} 3.177(7) \AA$ lower than the van der Waals radius of sulphur, corresponding to a reduction ratio of $88.2 \%$. Nevertheless, due to steric hindrance generated by the iodophenyl rings, these S...S contacts within these acceptors are less numerous than those observed with DEBTTT where extensive three-dimensional S...S interactions were noticed. ${ }^{9}$
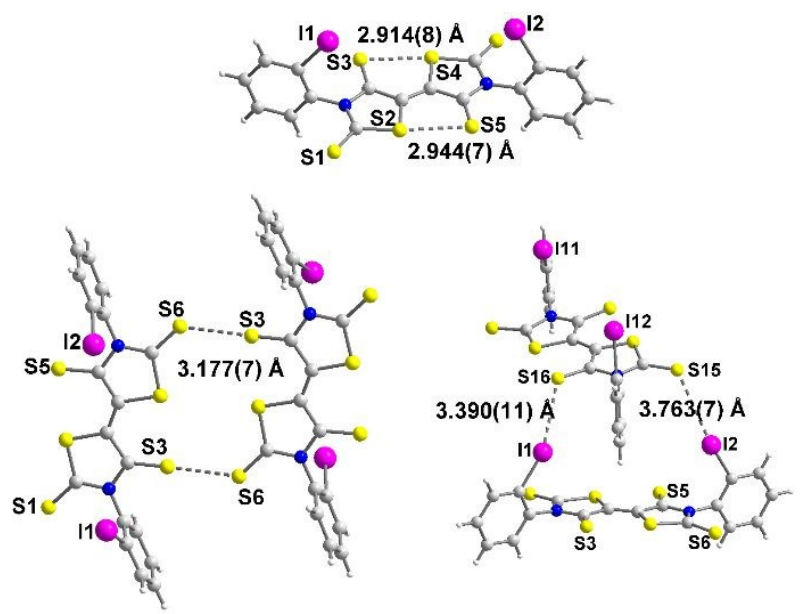

Fig. 3 Molecular structure of the acceptor $4 c$ showing the intramolecular S...S contacts (top), the shortest intermolecular contacts (bottom left) and the $\mathrm{XB}$ bonds between two neighbouring molecules (bottom right).

Electrostatic surface potential calculations have been performed on the optimized geometry of the four molecules that have been crystallographically characterized, namely $\mathbf{2 b}$, $\mathbf{3 a}, \mathbf{3 c}$ and $\mathbf{4 c}$. These calculations were carried out in order to estimate the halogen bond donor abilities of the iodophenyl substituent within these different structures and to rationalize the interactions taking place in the crystal. ${ }^{9}$ As shown in Figure $\mathbf{4}$, for $\mathbf{2} \mathbf{b}$ the maximum calculated positive electrostatic surface potential (ESP) is found at the hydrogen atoms located on the thiazole ring $\left(+31.74 \mathrm{kcal}^{\mathrm{mol}}{ }^{-1}\right)$ compared to only +23.89 $\mathrm{kcal} . \mathrm{mol}^{-1}$ at the iodine atom. The most negative calculated ESP is $-29.09 \mathrm{kcal}^{\mathrm{mol}} \mathrm{m}^{-1}$ and located on the thione's sulphur atom $(\mathrm{C}=\mathrm{S})$. This calculated charge repartition is in good agreement with the organization of the molecule $\mathbf{2} \mathbf{b}$ in the solid state where predominant hydrogen bonding interactions were observed between the hydogen atom on the thiazoline ring and the sulphur atom of the thione, while no specific halogen bonding interaction involving the iodine atom was detected. 

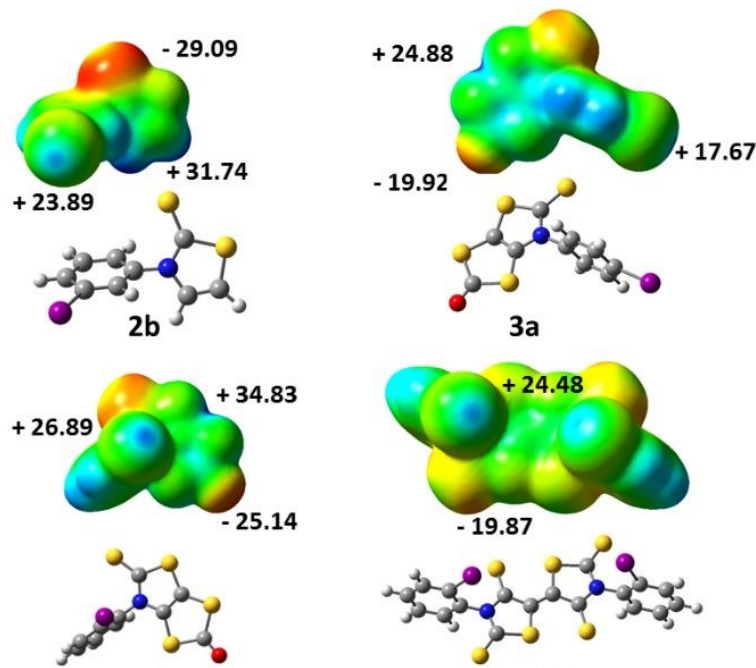

$3 c$

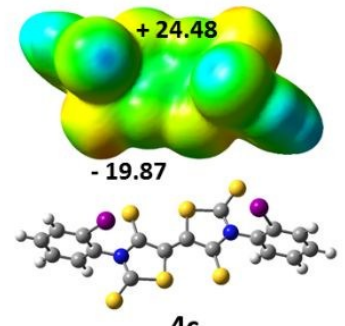

$4 c$

Fig. 5 Molecular electrostatic potential surface mapped at the $0.001 \mathrm{e}^{-} . \mathrm{au}^{-3}$ isodensity surface for $\mathbf{4 a}$ and $\mathbf{4 b}$. The colour scales range from $-29 \mathrm{kcal}^{\mathrm{mol}}{ }^{-1}$ (red) to $+35 \mathrm{kcal}^{\mathrm{mol}} \mathrm{m}^{-1}$ (blue).

We also performed some ESP calculations for the two other acceptors that have not been crystallographically characterized in order to analyse the influence of the localization of the halogen atom. For both acceptors, $\mathbf{4} \mathbf{a}$ and $\mathbf{4} \mathbf{b}$, the most negative calculated ESP is located on the thione's sulphur atom ( $C=S)$ as for the acceptor $\mathbf{4 c}$. On the other hand, the highest ESP value over the whole molecules $\mathbf{4 a}$ and $\mathbf{4 b}$ is not found at the $\sigma$-hole like for $4 \mathbf{c}$ (Figure 5) but located para to the iodine atom on the aromatic ring, potentially a less favorable charge distribution for the growing of crytals in these cases.

\section{Conclusions}

In this study we investigated the synthesis of sulphur-rich electron $\pi$ acceptors, the bithiazolidinylidenes, substituted by iodophenyl substituents, which can act as halogen bond donor toward thione $(C=S)$ or ketone $(C=O)$ groups acting as $X B$ acceptors. Single crystals of the synthetic intermediates as well as one of the acceptors have been obtained. For the precursors, when the thione $(\mathrm{C}=\mathrm{S})$ and ketone $(\mathrm{C}=\mathrm{O})$ groups are present on the molecule, a halogen bond is formed between the iodine atom of one molecule and the $\mathrm{C}=\mathrm{S} / \mathrm{C}=\mathrm{O}$ moieties of the neighbouring ones. For the acceptor $\mathbf{4 c}$, in accordance with the calculated ESP maxima, $\mathrm{I} \cdots \mathrm{S}=\mathrm{C}$ halogen bonds are observed between neighbouring molecules as well as $\mathrm{S} \cdots \mathrm{S}$ interactions. Thus we managed to generate from these BIPBTTT acceptors the coexistence of two types of intermolecular interactions in the solid state. The next step will be the design of sulphur-rich electron acceptor substituted by groups bearing an iodine atom but less bulky than phenyl in order to increase the strength of the intermolecular interactions.

\section{Experimental section}

All commercial chemicals were used without further purification. The solvents were purified and dried by standard methods. All the NMR spectra were obtained in $\mathrm{CDCl}_{3}$ unless indicated otherwise. Chemical shifts are reported in ppm and ${ }^{1} \mathrm{H}$ NMR spectra were referenced to residual $\mathrm{CHCl}_{3}(7.26 \mathrm{ppm})$ and ${ }^{13} \mathrm{C}$ NMR spectra were referenced to $\mathrm{CHCl}_{3}$ (77.2 ppm). The ${ }^{13} \mathrm{C}$ NMR spectra of the acceptors $4 \mathrm{a}-\mathrm{c}$ could not be obtained due to their low solubility. Melting points were measured on a Kofler hot-stage apparatus and are uncorrected. Mass spectra and Elemental analyses were performed at the Centre Régional de Mesures Physiques de l'Ouest, Rennes. Cyclic voltammetry were carried out on a $10^{-3} \mathrm{M}$ solution in $\mathrm{CH}_{2} \mathrm{Cl}_{2}$, containing $0.1 \quad \mathrm{M} \quad n \mathrm{Bu}_{4} \mathrm{NPF}_{6}$ as supporting electrolyte. Voltammograms were recorded at $0.1 \mathrm{Vs}^{-1}$ on a platinum electrode and the potentials were measured versus the Saturated Calomel Electrode (SCE).

N-iodophenyl-1,3-thiazoline-2-thione 2a-c : To a solution of 4iodoaniline, 3-iodoaniline or 2-iodoaniline (12 g, $54.8 \mathrm{mmol})$ was added $100 \mathrm{~mL}$ of triethylamine and $100 \mathrm{~mL}$ of carbon disulphide. The solution was stirred under argon $24 \mathrm{~h}$. The solution was filtered and 
the yellow solid was washed with diethylether. The dithiocarbamate salts 1a-c were used without further purification; 1a: yield: $95 \%, \mathrm{Mp}$ : $92^{\circ} \mathrm{C} .{ }^{1} \mathrm{H}$ NMR $(300 \mathrm{MHz}) \delta 1.30\left(\mathrm{t}, 9 \mathrm{H},{ }^{3} \mathrm{~J}=7.3 \mathrm{~Hz}, \mathrm{CH}_{3}\right), 3.17(\mathrm{q}, 6 \mathrm{H}$, $\left.{ }^{3} \mathrm{~J}=7.3 \mathrm{~Hz}, \mathrm{CH}_{2}\right), 7.43(\mathrm{~m}, 2 \mathrm{H}, \mathrm{Ar}), 7.53(\mathrm{~m}, 2 \mathrm{H}, \mathrm{Ar}), 9.45(\mathrm{~s}, 1 \mathrm{H}, \mathrm{NH}) ;{ }^{13} \mathrm{C}$ NMR $(75 \mathrm{MHz}) \delta 8.8\left(\mathrm{CH}_{3}\right), 46.0\left(\mathrm{CH}_{2}\right), 88.2(\mathrm{Ar}), 125.2(\mathrm{Ar}), 137.7(\mathrm{Ar})$, 140.8 (Ar), $214.3(\mathrm{C}=\mathrm{S}) ; \mathbf{1 b}$ : yield: $97 \%$; $\mathrm{Mp}: 100^{\circ} \mathrm{C} ;{ }^{1} \mathrm{H}$ NMR $(300$ $\mathrm{MHz}) \delta 1.36\left(\mathrm{t}, 9 \mathrm{H},{ }^{3} \mathrm{~J}=7.3 \mathrm{~Hz}, \mathrm{CH}_{3}\right), 3.23\left(\mathrm{q}, 6 \mathrm{H},{ }^{3} \mathrm{~J}=7.3 \mathrm{~Hz}, \mathrm{CH}_{2}\right), 6.99(\mathrm{t}$, $\left.1 \mathrm{H},{ }^{3} \mathrm{~J}=8.1 \mathrm{~Hz}, \mathrm{Ar}\right), 7.39\left(\mathrm{~d}, 1 \mathrm{H},{ }^{3} \mathrm{~J}=8.1 \mathrm{~Hz}, \mathrm{Ar}\right), 7.62\left(\mathrm{~d}, 1 \mathrm{H},{ }^{3} \mathrm{~J}=8.1 \mathrm{~Hz}, \mathrm{Ar}\right)$, $8.10(\mathrm{~s}, 1 \mathrm{H}, \mathrm{Ar}), 9.40(\mathrm{~s}, 1 \mathrm{H}, \mathrm{NH}) ;{ }^{13} \mathrm{C} \mathrm{NMR}(75 \mathrm{MHz}) \delta 8.8\left(\mathrm{CH}_{3}\right), 46.0$ $\left(\mathrm{CH}_{2}\right), 93.3(\mathrm{Ar}), 122.8(\mathrm{Ar}), 129.7(\mathrm{Ar}), 131.8(\mathrm{Ar}), 133.3(\mathrm{Ar}), 142.1$ (Ar), 214.7 (C=S); 1c: yield : 92\%; Mp: $95{ }^{\circ} \mathrm{C} ;{ }^{1} \mathrm{H}$ NMR (300 MHz) $\delta 1.36$ $\left(\mathrm{t}, 9 \mathrm{H},{ }^{3} \mathrm{~J}=7.3 \mathrm{~Hz}, \mathrm{CH}_{3}\right), 3.22\left(\mathrm{q}, 6 \mathrm{H},{ }^{3} \mathrm{~J}=7.3 \mathrm{~Hz}, \mathrm{CH}_{2}\right), 6.85(\mathrm{~m}, 1 \mathrm{H}, \mathrm{Ar})$, $7.31(\mathrm{~m}, 1 \mathrm{H}, \mathrm{Ar}), 7.78\left(\mathrm{~d}, 1 \mathrm{H},{ }^{3} \mathrm{~J}=8.1 \mathrm{~Hz}, \mathrm{Ar}\right), 8.08\left(\mathrm{~d}, 1 \mathrm{H},{ }^{3} \mathrm{~J}=8.1 \mathrm{~Hz}, \mathrm{Ar}\right)$, $9.02(\mathrm{~s}, 1 \mathrm{H}, \mathrm{NH}) ;{ }^{13} \mathrm{CNMR}(75 \mathrm{MHz}) \delta 9.2\left(\mathrm{CH}_{3}\right) ; 46.0\left(\mathrm{CH}_{2}\right) ; 95.0(\mathrm{Ar})$; 114.8 (Ar) ; 127.7 (Ar) ; 128.8 (Ar) ; 138.8 (Ar) ; 142.2 (Ar) ; 215.5 $(\mathrm{C}=\mathrm{S})$; To a solution of the dithiocarmate salt (1a-c) (20.6 g, 52.0 $\mathrm{mmol}$ ) was added 1 equivalent of chloroacetaldehyde $(0.96 \mathrm{~mL}, 52.0$ $\mathrm{mmol})$. The solution was stirred for $12 \mathrm{~h}$ at $\mathrm{rt}$ and $9 / 10$ of the solvent was evaporated in vacuo. The mixture was added to $15 \mathrm{~mL}$ of $\mathrm{H}_{2} \mathrm{SO}_{4}$ at $0^{\circ} \mathrm{C}$ and stirred for further 10 minutes. The solution was extracted with $\mathrm{CH}_{2} \mathrm{Cl}_{2}(3 \times 50 \mathrm{~mL})$, washed with water $(3 \times 20 \mathrm{~mL})$ and dried over $\mathrm{MgSO}_{4}$. The precipitate was washed with ethanol. Brown powders were obtained.

2a: yield: $71 \% ; \mathrm{Mp}=211^{\circ} \mathrm{C} ;{ }^{1} \mathrm{H}$ NMR $(300 \mathrm{MHz}) \delta 6.67(\mathrm{~d}, 1 \mathrm{H}$, $\left.{ }^{3} \mathrm{~J}=4,7 \mathrm{~Hz}, \mathrm{SCH}\right), 7.08\left(\mathrm{~d}, 1 \mathrm{H},{ }^{3} \mathrm{~J}=4,7 \mathrm{~Hz}, \mathrm{NCH}\right), 7.27\left(\mathrm{~d}, 2 \mathrm{H},{ }^{3} \mathrm{~J}=4,7 \mathrm{~Hz}, \mathrm{Ar}\right)$, 7.85 (d, 2H, $\left.{ }^{3} \mathrm{~J}=4,7 \mathrm{~Hz}, \mathrm{Ar}\right) ;{ }^{13} \mathrm{C} \mathrm{NMR}(75 \mathrm{MHz}) 95.0(\mathrm{Ar}), 111.6$ (C=C), 128.4 (2Ar), $132.1(\mathrm{C}=\mathrm{C}), 138.3$ (Ar), 138.9 (2Ar), 214.5 (C=S); HRMS (ESI) calcd for $\mathrm{C}_{9} \mathrm{H}_{6} \mathrm{INNaS}_{2}[\mathrm{M}+\mathrm{Na}]^{+}: 341.88786$. Found: 341.8882 ; Anal calcd for $\mathrm{C}_{9} \mathrm{H}_{6} \mathrm{INS}_{2}: \mathrm{C}, 33.87 ; \mathrm{H}, 1.89 ; \mathrm{N}, 4.39$. Found: $\mathrm{C}, 33.68 ; \mathrm{H}$, 1.82; N, 4.38.

2b: yield 87\%; Mp : $119^{\circ} \mathrm{C} ;{ }^{1} \mathrm{H}$ NMR $(300 \mathrm{MHz}) \delta 6.68\left(\mathrm{~d}, 1 \mathrm{H},{ }^{3} \mathrm{~J}=4.7 \mathrm{~Hz}\right.$, $\mathrm{SCH}), 7.10\left(\mathrm{~d}, 1 \mathrm{H},{ }^{3} \mathrm{~J}=4.7 \mathrm{~Hz}, \mathrm{NCH}\right), 7.24(\mathrm{~m}, 1 \mathrm{H}, \mathrm{Ar}), 7.51(\mathrm{~m}, 1 \mathrm{H}, \mathrm{Ar})$, $7.80(\mathrm{~m}, 2 \mathrm{H}, \mathrm{Ar}), 7.83 ;{ }^{13} \mathrm{C} \mathrm{NMR}(75 \mathrm{MHz}) \delta 93.9(\mathrm{Ar}), 111.6(\mathrm{C}=\mathrm{C})$, $126.1(\mathrm{C}=\mathrm{C}), 130.8(\mathrm{Ar}), 132.1(\mathrm{Ar}), 135.3(\mathrm{Ar}), 138.3(\mathrm{Ar}), 139.3(\mathrm{Ar})$, 188.7 (C=S); HRMS (ESI) calcd for $\mathrm{C}_{9} \mathrm{H}_{6} \mathrm{INNaS}_{2}[\mathrm{M}+\mathrm{Na}]^{+}: 341.88786$. Found: 341.8881. Anal calcd for $\mathrm{C}_{9} \mathrm{H}_{6} \mathrm{INS}_{2}: \mathrm{C}, 33.87 ; \mathrm{H}, 1.89 ; \mathrm{N}, 4.39$. Found $\mathrm{C}, 33.51 ; \mathrm{H}, 1.69 ; \mathrm{N}, 4.42$.

2c: yield 72\%; Mp : $180^{\circ} \mathrm{C}$; ${ }^{1} \mathrm{H}$ NMR (300 MHz) $\delta 6.71\left(\mathrm{~d}, 1 \mathrm{H},{ }^{3} \mathrm{~J}=4,7 \mathrm{~Hz}\right.$, $\mathrm{SCH}), 6.98\left(\mathrm{~d}, 1 \mathrm{H},{ }^{3} \mathrm{~J}=4,7 \mathrm{~Hz}, \mathrm{NCH}\right), 7.22(\mathrm{~m}, 1 \mathrm{H}, \mathrm{Ar}), 7.40(\mathrm{~m}, 1 \mathrm{H}, \mathrm{Ar})$, $7.52(\mathrm{~m}, 1 \mathrm{H}, \mathrm{Ar}), 7.99(\mathrm{~m}, 1 \mathrm{H}, \mathrm{Ar}) ;{ }^{13} \mathrm{CNMR}(75 \mathrm{MHz}) \delta 96.7$ (Ar), 111.7 $(\mathrm{C}=\mathrm{C}), 129.2(\mathrm{C}=\mathrm{C}), 129.8(\mathrm{Ar}), 131.4(2 \mathrm{Ar}), 140.4(\mathrm{Ar}), 141.5(\mathrm{Ar})$, 189.0 (C=S); HRMS (ESI) calcd for $\mathrm{C}_{9} \mathrm{H}_{6} \mathrm{INNaS}_{2}[\mathrm{M}+\mathrm{Na}]^{+}: 341.88786$. Found 341.8877. Anal calcd for $\mathrm{C}_{9} \mathrm{H}_{6} \mathrm{INS}_{2}$ : C, 33.87; $\mathrm{H}, 1.89 ; \mathrm{N}, 4.39$. Found: C, 33.76; H, 1.69; N, 4.44 .

Synthesis of bicycle $3 \mathrm{a}-\mathrm{c}$ : To a $-10^{\circ} \mathrm{C}$ cooled solution of thiazoline (2ac) $(1 \mathrm{~g}, 3.12 \mathrm{mmol})$ in $80 \mathrm{~mL}$ of dry THF under nitrogen was added a solution of LDA prepared from diisopropylamine $(0.66 \mathrm{ml}, 4.8 \mathrm{mmol})$ and $n$-BuLi $1.6 \mathrm{M}(2.93 \mathrm{~mL}, 4.8 \mathrm{mmol})$ in $10 \mathrm{~mL}$ of dry THF. After stirring for $30 \mathrm{~min}$ at $-10^{\circ} \mathrm{C}$, sulphur $\mathrm{S}_{8}(150 \mathrm{mg}, 4.8 \mathrm{mmol})$ was added and the solution was stirred for an additional $30 \mathrm{~min}$. A solution of LDA diisopropylamine $(0.88 \mathrm{~mL}, 6.24 \mathrm{mmol})$ and $n$-BuLi $(3.9 \mathrm{~mL}, 6.24$ $\mathrm{mmol}$ ) in $15 \mathrm{~mL}$ of dry THF was added. The mixture was stirred for 3 hours and $\mathrm{S}_{8}(200 \mathrm{mg}, 6.24 \mathrm{mmol})$ was added. After $30 \mathrm{~min}$, triphosgene $(1.11 \mathrm{~g}, 3.7 \mathrm{mmol})$ was added to the reaction mixture. The reaction was stirred overnight and water $(15 \mathrm{~mL})$ was slowly added. The solvent was evaporated in vacuo. Dichloromethane (50
$\mathrm{mL}$ ) was added and the solution was washed with water $(3 \times 20 \mathrm{~mL})$ and dried over $\mathrm{MgSO}_{4}$. The concentrated solution was purified by chromatography on silica gel using $\mathrm{CH}_{2} \mathrm{Cl}_{2}$-petroleum ether as the eluent. Brown powders were obtained for $\mathbf{3 a}$ and $\mathbf{3 c}$. $\mathbf{3 b}$ was not isolated, the crude oil was used without further purification.

3a : yield : $36 \% ; \mathrm{Mp}=174^{\circ} \mathrm{C} ;{ }^{1} \mathrm{H} \mathrm{NMR} \mathrm{(300} \mathrm{MHz)} \delta 7.20(\mathrm{~m}, 2 \mathrm{H}, \mathrm{Ar})$; $7.92(\mathrm{~m}, 2 \mathrm{H}, \mathrm{Ar}) .{ }^{13} \mathrm{C} \mathrm{NMR}\left(\mathrm{CDCl}_{3}, 75 \mathrm{MHz}\right) \delta=96.8(\mathrm{Ar}), 102.1(\mathrm{C}=\mathrm{C})$, $127.1(\mathrm{C}=\mathrm{C}), 128.3$ (2Ar), 137.2 (Ar), $139.6(2 \mathrm{Ar}), 186.1(\mathrm{C}=\mathrm{S}), 188.1$ $(\mathrm{C}=0)$; IR $v_{(\mathrm{C}=\mathrm{S})}: 1261 \mathrm{~cm}^{-1}, v_{(\mathrm{C}=0)}: 1695 \mathrm{~cm}^{-1}$; HRMS (ESI) calcd for $\mathrm{C}_{10} \mathrm{H}_{4} \mathrm{INOS}_{4}[\mathrm{M}+\mathrm{H}]^{+}:$409.82933. Found: 409.8296; Anal. calcd for $\mathrm{C}_{10} \mathrm{H}_{4} \mathrm{INOS}_{4}$ : C, 29.34; H, 0.99; N, 3.42. Found: C, 29.68; H, 1.06; N, 3.50 .

$3 \mathrm{c}$ : yield : $60 \% ; \mathrm{Mp}=200^{\circ} \mathrm{C} ;{ }^{1} \mathrm{H} \mathrm{NMR}(300 \mathrm{MHz}) \delta 7.29(\mathrm{~m}, 1 \mathrm{H}$, $\mathrm{Ar}), 7.44(\mathrm{~m}, 1 \mathrm{H}, \mathrm{Ar}), 7.58(\mathrm{~m}, 1 \mathrm{H}, \mathrm{Ar}), 8.02(\mathrm{~m}, 1 \mathrm{H}, \mathrm{Ar}) ;{ }^{13} \mathrm{C} N M R$ (75 MHz) $\delta 94.2(\mathrm{Ar}), 108.1(\mathrm{C}=\mathrm{C}), 112.6(\mathrm{C}=\mathrm{C}), 131.1(\mathrm{Ar}), 131.7$ (Ar), 138.8 (Ar), $139.4(\mathrm{Ar}), 143.7(\mathrm{Ar}), 191.6(\mathrm{C}=\mathrm{S}), 192.1(\mathrm{C}=0)$; IR $v_{(\mathrm{C}=\mathrm{S})}: 1289 \mathrm{~nm}, \mathrm{IR} v_{(\mathrm{C}=0)}: 1660 \mathrm{~nm}$; HRMS (ESI) calcd for $\mathrm{C}_{10} \mathrm{H}_{4} \mathrm{INOS}_{4}[\mathrm{M}+\mathrm{H}]^{+}:$431.81127. Found: 431.8110; Anal. calcd for $\mathrm{C}_{10} \mathrm{H}_{4} \mathrm{INOS}_{4}$ : C, 29.34; $\mathrm{H}, 0.99 ; \mathrm{N}, 3.42$.Found: C, 29.65; $\mathrm{H}$, $0.92 ; \mathrm{N}, 3.21$.

Synthesis of BIP-BTTT 4a-c. A solution of thiazoline-thione 3a-c (243mg, $0.59 \mathrm{mmol}$ ), (crude compound for $3 \mathbf{b}$ ) in $30 \mathrm{~mL}$ of toluene was refluxed for $16 \mathrm{~h} .80 \%$ of the solvent was removed in vacuo and the concentrated solution was filtrated and the precipitate was washed with ethanol. Dark purple powders were obtained. Crystals of $\mathbf{4 c}$ of sufficient quality for $\mathrm{X}$-ray diffraction were obtained by slow evaporation of $\mathrm{CHCl}_{3}$ solution.

4a: yield: $72 \%, \mathrm{Mp}>250^{\circ} \mathrm{C}$; . ${ }^{1} \mathrm{H} N M R\left(\mathrm{CS}_{2}, 300 \mathrm{MHz}\right) \delta 7.08(\mathrm{~d}, 4 \mathrm{H}$, $\mathrm{Ar}), 7.89$ (d, $4 \mathrm{H}, \mathrm{Ar}$ ); HRMS (ESI) calcd for $\mathrm{C}_{18} \mathrm{H}_{9} \mathrm{~N}_{2} \mathrm{IS}_{6}[\mathrm{M}]^{+}: 697.70958$. Found 697.7101; UV-vis $\left(\mathrm{CHCl}_{2}\right) \lambda_{\max }(\mathrm{nm}) \quad\left(\varepsilon\left[\mathrm{L} \cdot \mathrm{mol}^{-1} \cdot \mathrm{cm}^{-1}\right]\right)=242$ (24640), 358 (11500), 520 (2550); Anal. calcd for $\left[\mathrm{C}_{18} \mathrm{H}_{8} \mathrm{I}_{2} \mathrm{~N}_{2} \mathrm{~S}_{6}+\right.$ Toluene (8/1)]: C, $31.93 ; \mathrm{H}, 1.28$; N, 3.95. Found: C, 32.08 ; H, 1.27 ; N, 3.95 .

4b: yield : $30 \%$ (calculated from $2 \mathrm{~b}$ ), $\mathrm{mp}>250^{\circ} \mathrm{C}$; ${ }^{1} \mathrm{H}$ NMR $\left(\mathrm{CS}_{2}, 300\right.$ $\mathrm{MHz}) \delta 7.18(\mathrm{~m}, 2 \mathrm{H}, \mathrm{Ar}), 7.32(\mathrm{~m}, 2 \mathrm{H}, \mathrm{Ar}), 7.52(\mathrm{~m}, 2 \mathrm{H}, \mathrm{Ar}), 7.83(\mathrm{~m}$, $2 \mathrm{H}, \mathrm{Ar})$; UV-vis $\left(\mathrm{CHCl}_{2}\right) \lambda_{\max }(\mathrm{nm})\left(\varepsilon\left[\mathrm{L} \cdot \mathrm{mol}^{-1} . \mathrm{cm}^{-1}\right]\right)=232(36060), 359$ (18370), 512(3420); HRMS (ESI) calcd for $\mathrm{C}_{18} \mathrm{H}_{9} \mathrm{~N}_{2} \mathrm{IS}_{6}[\mathrm{M}+\mathrm{Na}]^{+}$: 720.69935. Found 720.6993. Analysis calcd for $\left[\mathrm{C}_{18} \mathrm{H}_{8} \mathrm{I}_{2} \mathrm{~N}_{2} \mathrm{~S}_{6}+\right.$ Toluene (8/1)]: C, $31.93 ; H, 1.28 ; N, 3.95$. Found: C, $32.04 ; H, 1.32 ; N, 4.18$. 4c: yield : $60 \%, \mathrm{mp}=200^{\circ} \mathrm{C} .{ }^{1} \mathrm{H} \mathrm{NMR}(300 \mathrm{MHz}) \delta 7.27(\mathrm{~m}, 2 \mathrm{H}$, Ar), $7.41(\mathrm{~m}, 2 \mathrm{H}, \mathrm{Ar}), 7.54(\mathrm{~m}, 2 \mathrm{H}, \mathrm{Ar}), 8.02(\mathrm{~m}, 2 \mathrm{H}, \mathrm{Ar})$; UV-vis $\left(\mathrm{CHCl}_{2}\right) \quad \lambda_{\max }(\mathrm{nm}) \quad\left(\varepsilon\left[\mathrm{L}_{\mathrm{mol}}{ }^{-1} . \mathrm{cm}^{-1}\right]\right): 226(28670), \quad 358(14928)$, 511(2270); HRMS (ESI) calcd for $\mathrm{C}_{18} \mathrm{H}_{9} \mathrm{~N}_{2} \mathrm{IS}_{6}$ [M] $^{-}: 697.71068$. Found: 697.7107; Analysis calcd for $\left[\mathrm{C}_{18} \mathrm{H}_{8} \mathrm{I}_{2} \mathrm{~N}_{2} \mathrm{~S}_{6}+\right.$ Toluene (8/1)]: C, 31.93 ; H, 1.28 ; N, 3.95. Found: C, $31.77 ; H, 1.25$; N, 3.96 .

\section{Crystallography}

Data were collected on a D8 VENTURE Bruker AXS diffractometer with graphite-monochromated Mo-K $\alpha$ radiation $(\lambda=0.71073 \AA$ ) for 2b, 3a, 3c and $\mathbf{4 c}$ The structures were solved by dual-space algorithm using the SHELXT program, ${ }^{17}$ and then refined with full-matrix leastsquare methods based on $F^{2}$ (SHELXL). ${ }^{18}$ All non-hydrogen atoms were refined with anisotropic atomic displacement parameters. $\mathrm{H}$ atoms were finally included in their calculated positions. Concerning 
3a, the use of Platon/TwinRotMat ${ }^{19}$ routine allowed to detect the presence of a twinning in the measured crystal. Satisfactory final structural refinement has been performed considering the presence of such a twinning and on the hklf5 file format, leading to a refined twin ratio of 0.19 . Crystallographic data on X-ray data collection and structure refinements are given in Table 3

Table 3 Crystallographic data

\begin{tabular}{|c|c|c|c|c|}
\hline Compound & $2 b$ & $3 a$ & $3 c$ & $4 c$ \\
\hline Formula & $\mathrm{C}_{9} \mathrm{H}_{6} \mathrm{INS}_{2}$ & $\mathrm{C}_{10} \mathrm{H}_{4} \mathrm{INOS}_{4}$ & $\begin{array}{c}\mathrm{C}_{10} \mathrm{H}_{4} \text { INOS } \\
4\end{array}$ & $\mathrm{C}_{18} \mathrm{H}_{8} \mathrm{I}_{2} \mathrm{~N}_{2} \mathrm{~S}_{6}$ \\
\hline $\begin{array}{c}\mathrm{FW} \\
\left(\mathrm{g} \cdot \mathrm{mol}^{-1}\right)\end{array}$ & 319.17 & 409.28 & 409.28 & 698.42 \\
\hline $\begin{array}{l}\text { Crystal } \\
\text { system }\end{array}$ & monoclinic & monoclinic & monoclinic & triclinic \\
\hline Space group & $C 2 / c$ & $P 2_{1} / \mathrm{n}$ & $P 2_{1} / c$ & $P-1$ \\
\hline$a(\AA ̊ \cap)$ & $8.7777(10)$ & $4.1078(7)$ & $8.1394(7)$ & $12.5260(18)$ \\
\hline$b(\AA ̊)$ & $11.1568(15)$ & $24.675(5)$ & $6.9798(7)$ & $14.352(2)$ \\
\hline$c(\AA ̊)$ & $21.241(3)$ & $13.943(3)$ & $22.487(2)$ & $14.522(2)$ \\
\hline$\alpha\left(^{\circ}\right)$ & 90 & 90 & 90 & 117.141(4) \\
\hline$\beta\left(^{\circ}\right)$ & $96.632(4)$ & $118.785(7)$ & $94.788(3)$ & $95.478(5)$ \\
\hline$\gamma\left({ }^{\circ}\right)$ & 90 & 90 & 90 & $100.638(5)$ \\
\hline$V\left(\AA^{3}\right)$ & $2066.3(5)$ & $1238.6(4)$ & $1273.1(2)$ & $2234.7(6)$ \\
\hline$T(\mathrm{~K})$ & $150(2)$ & $150(2)$ & $150(2)$ & $150(2)$ \\
\hline$Z$ & 8 & 4 & 4 & 4 \\
\hline$D_{\text {calc }}\left(\mathrm{g} \cdot \mathrm{cm}^{-3}\right)$ & 2.052 & 2.195 & 2.135 & 2.076 \\
\hline$\mu\left(\mathrm{mm}^{-1}\right)$ & 3.454 & 3.238 & 3.151 & 3.384 \\
\hline Total refls. & 8223 & 11687 & 14751 & 51086 \\
\hline Abs. Corr. & multi-scan & multi-scan & multi-scan & multi-scan \\
\hline Uniq. refls. & 2344 & - & 2904 & 10225 \\
\hline$\left(R_{\text {int }}\right)$ & $(0.0274)$ & & $(0.0404)$ & $(0.1050)$ \\
\hline $\begin{array}{l}\text { Uniq. refls. } \\
\qquad(I>2 \sigma(I))\end{array}$ & 2188 & 8472 & 2675 & 6098 \\
\hline$R_{1}, w R_{2}$ & $\begin{array}{l}0.0307 \\
0.0974\end{array}$ & $\begin{array}{l}0.0758 \\
0.1622\end{array}$ & $\begin{array}{l}0.0306 \\
0.0814\end{array}$ & $\begin{array}{l}0.1160 \\
0.3164\end{array}$ \\
\hline $\begin{array}{c}R_{1}, w R_{2} \\
\text { (all data) }\end{array}$ & $\begin{array}{l}0.0336 \\
0.1095\end{array}$ & $\begin{array}{l}0.1094 \\
0.1758\end{array}$ & $\begin{array}{l}0.0337 \\
0.0834\end{array}$ & $\begin{array}{l}0.1793 \\
0.3626\end{array}$ \\
\hline GoF & 1.101 & 1.042 & 1.054 & 1.079 \\
\hline
\end{tabular}

\section{Theoretical Modeling}

Electrostatic Surface Potential calculations were carried out on the optimized geometry of the molecules (with Density Functional Theory using the Gaussian 09 Revision D.01 software, the B3LYP functional and the $6-31+G^{* *}$ basis set for all atoms and the LANLdp basis set for iodine). GaussView 5.0.9 was used to generate the figures.
5 E. D. Głowacki, M. Irimia-Vladu, S. Bauer and N. S. Sariciftci, J. Mater. Chem. B, 2013, 1, 3742-3753.

6 K. S. Kim, P. Tarakeshwar and J. Y. Lee, Chem. Rev., 2000, 100, 4145-4185.

7 (a) G. Cavallo, P. Metrangolo, R. Milani, T. Pilati, A. Priimagi, G. Resnati and G. Terraneo, Chem. Rev., 2016, 116, 24782601. (b) L. C. Gilday, S. W. Robinson, T. A. Barendt, M. J. Langton, B. R. Mullaney and P. D. Beer, Chem. Rev., 2015, 115, 7118-7195(a) G. Cavallo, P. Metrangolo, R. Milani, T. Pilati, A. Priimagi, G. Resnati and G. Terraneo, Chem. Rev., 2016, 116, 2478-2601. (b) L. C. Gilday, S. W. Robinson, T. A. Barendt, M. J. Langton, B. R. Mullaney and P. D. Beer, Chem. Rev., 2015, 115, 7118-7195.

8 A. S. Mahadevi and G. N. Sastry, Chem. Rev., 2016, 116, 27752825

9 (a) Y. Le Gal, N. Bellec, F. Barrière, R. Clérac, M. Fourmigué, V. Dorcet, T. Roisnel, and D. Lorcy, Dalton Trans., 2013, 42, 16672-16679. (b) Y. Le Gal, D. Ameline, N. Bellec, A. Vacher, T. Roisnel, V. Dorcet, O. Jeannin and D. Lorcy, Org. Biomol. Chem., 2015, 13, 8479-8486. (c) Y. Le Gal, M. Rajkumar, A. Vacher, V. Dorcet, T. Roisnel, M. Fourmigué, F. Barrière, T. Guizouarn and D. Lorcy, CrysEngComm. 2016, 18, 3925-3933.

10 A. Filatre-Furcate, T. Higashino, D. Lorcy and T. Mori, J. Mater. Chem. C, 2015, 3, 3569-3573.

11 (a) K. lijima, Y. Le Gal, T. Higashino, D. Lorcy, T. Mori, J. Mater. Chem. C, 2017, 5, 9121-9127. (b) K. lijima, Y. Le Gal, D. Lorcy and T. Mori, RSC Adv., 2018, 8, 18400-18405.

12 C. Wang, H. Dong, W. Hu, Y. Liu and D. Zhu, Chem. Rev., 2012, 112, 2208-2267.

13 Y. Le Gal, D. Lorcy, O. Jeannin, F. Barrière, V. Dorcet, J. Lieffrig and M. Fourmigué, CrystEngComm., 2016, 18, 5474-5481.

14 M. L. Kaplan, R. C. Haddon, F. B. Bramwell, F. Wudl, J. H. Marshall, D. O. Cowan and S. Gronowitz, J. Phys. Chem., 1980, 84, 427-431.

15 M. Arca, M. C. Aragoni, F. A. Devillanova, A. Garau, F. Isaia, V. Lippolis, A. Mancini and G. Verani, Bioinorg. Chem. Appl., 2006, 58937.

16 P. Auffinger, F. A. Hays, E. Westhof and P. S. Ho, Proc. Natl. Acad. Sci. USA, 2004, 101,16789-16794.

17 G. M. Sheldrick, Acta Cryst., 2015, A71, 3-8.

18 G. M. Sheldrick, Acta Cryst., 2015, C71, 3-8.

19 A. L. Spek, Acta Cryst., 1990, A46, C34.

\section{Notes and references}

1 S. Sutton, C. Risko and J. L. Brédas, Chem. Mater., 2016, 28, 316.

2 G. R. Desiraju, J. Am. Chem. Soc., 2013, 135, 9952-9967.

3 R. Gleiter, G. Haberhauer, D. B. Werz, F. Rominger and C. Bleiholder, Chem. Rev., 2018, 118, 2010-2041.

4 G. R. Desiraju, Cryst. Growth Des., 2011, 11, 896-898. 


\section{Graphical abstract}

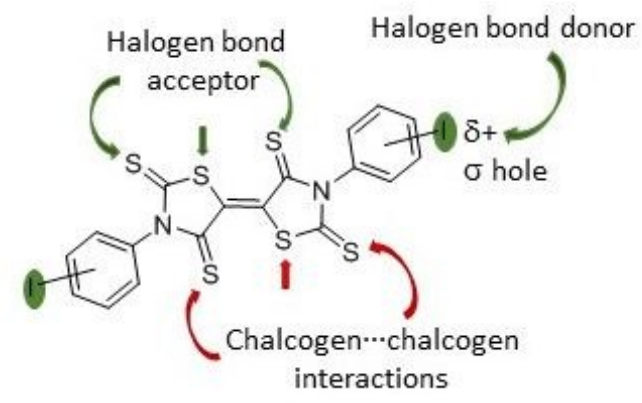

Sulphur and iodine heteroatoms on the acceptor skeleton induce chalcogen $\cdots$ chalcogen and halogen-bonding interactions. 